\title{
Inkomster över livs- och familjecykeln
}

Tobias Karlsson \& Christer Lundh

Klyftorna mellan rika och fattiga var betydande i det tidiga 1900-talets Göteborg. I detta kapitel riktar vi uppmärksamheten mot hur inkomsterna varierade med ålder för individer ur olika grupper och mellan olika faser i familjecykeln. Hur såg de typiska inkomstkarriärerna ut för män och kvinnor och för arbetare och tjänstemän? Hur förändrades hushållets samlade inkomster och levnadsstandard när barn kom till, växte upp och lämnade föräldrahemmet?

\section{Inkomstprofiler}

Åldersspecifika inkomstprofiler är intressanta i sig eftersom de ger en bild av individers och familjers livscykler, och de har också betydelse för en rad problemställningar i den ekonomiska och sociala historien. Inte minst inom den arbetsmarknadshistoriska forskningen studeras löneskillnader mellan olika grupper. Ökad kunskap om sambanden mellan ålder och inkomster på individnivå gör det enklare att dra slutsatser om exempelvis varför lönegapet mellan män och kvinnor ökade under vissa perioder och minskade under andra perioder. Detsamma gäller skillnader mellan arbetares och tjänstemäns löner. Om det är så att arbetar- och tjänstemannahushåll har olika inkomstprofiler kan inkomstspridningen i ett samhälle påverkas av förändringar i ålderssammansättning och hushållsstruktur. 
Även om vi i detta kapitel inte ställer inkomster i relation till individers och hushålls utgifter bidrar resultaten slutligen också till forskningen om levnadsstandard och sparande, som ofta har ett uttalat livscykelperspektiv. ${ }^{1}$

Vi inleder detta kapitel med ett avsnitt om arbetsinkomsternas förändring över individens livscykel mer generellt, utifrån tidigare forskning på data från olika tidsperioder och sammanhang. Därefter går vi in i de mönster som framträder i Göteborg, baserat på data från Göteborgs befolkningspanel (GOPP). ${ }^{2}$ Här riktar vi blicken mot skillnader mellan män och kvinnor samt mellan verkstadsarbetare och ingenjörer, två yrkesgrupper som får representera arbetare och tjänstemän. Längre fram i kapitlet skiftar vi fokus från individen till hushållet, först genom att studera inkomstskillnader mellan gifta och ogifta personer, därefter genom att visa hur inkomsterna, och barnens bidrag till dessa inkomster, förändrades över familjecykeln.

\section{Arbetsinkomstens förändring över individens livscykel}

Forskare har länge intresserat sig för sambandet mellan ålder (eller erfarenhet) och inkomster. Inriktningen fick ett uppsving i USA på 1950-talet och handlade då mycket om att studera avkastningen på investeringar i "humankapital", exempelvis skolutbildning och lärande på arbetsplatsen (on-the-job training). Dessa forskare, med Gary Becker i spetsen, hade tillgång till data på individnivå från amerikanska folkräkningar som innehöll uppgifter om ålder, utbildning och inkomster. ${ }^{3}$ Deras studier visade hur inkomsterna förändrades över livscykeln på ett sätt som överensstämde med de teoretiska förväntningarna: i yngre år drog man på sig kostnader för investeringar i humankapital, och när man blev äldre gav humankapitalet avkastning. Resultaten åskådliggjordes av konkava kurvor i diagram över sambandet mellan ålder och inkomst: en stark inkomstökning i unga år och avtagande ökningstakt med stigande ålder. Mot slutet av yrkeslivet började årsinkomsterna sjunka till följd av att äldre personer arbetade färre veckor per år. För arbetare med 5-7 års skolgång, det 
vill säga motsvarande svensk folkskola, uppnåddes den maximala årsinkomsten mellan 35 och 40 år. ${ }^{4}$ Fram till 6o-årsåldern förblev inkomsten i det närmaste oförändrad för att därefter börja falla.

Utifrån sina studier av sambandet mellan ålder (eller erfarenhet) och inkomst föreslog Jacob Mincer en empirisk modell enligt vilken den procentuella förändringen av en individs inkomst bestämdes av antalet skolår och erfarenheten. ${ }^{5}$ Erfarenheten skulle representera de investeringar i humankapital som gjordes på arbetsplatsen och ingick i ekvationen både som en linjär och som en kvadrerad term. Detta för att åstadkomma den konkava inkomstprofilen som kunde observeras i data.

Den så kallade Mincerekvationen fick på grund av sin enkelhet, och den ökade tillgången på mikrodata, ett massivt genomslag. En forskningsöversikt 2018 samlade över 1000 empiriska uppskattningar av avkastningen på utbildning som genomförts på data från 139 länder från 1950 till 2014, och nästan alla dessa uppskattningar antog att sambandet mellan ålder/erfarenhet och inkomster hade den konkava form som Mincer föreslog. ${ }^{6}$

En viktig fråga för ekonomisk-historiker är om det samband mellan ålder och inkomster som kunnat iakttas från 1950-talet och framåt även gällde under äldre tider. Det finns ett par intressanta studier på data från 180o-talet, den tidigindustriella epoken, som tyder på att sambandet har förändrats. Timothy Hatton har analyserat två amerikanska arbetsstatistiska undersökningar från 1890-talet och menar att den typiske arbetarens inkomstkarriär bestod av två distinkta faser. ${ }^{7}$ Under den första fasen, ungefär fram till 25 års ålder, steg arbetarens inkomst mycket snabbt. Vid 25 års ålder vidtog en platå, och inkomsten låg kvar på en jämn nivå fram till arbetslivets slut. Ett liknande mönster fann Maria Stanfors och Joyce Burnette i data från en arbetsstatistisk undersökning av den svenska tobaksindustrin år 1898. Där nådde emellertid arbetarna sin inkomstplatå tidigare, vid 23 års ålder, när de i genomsnitt hade arbetat i industrin i fyra år. ${ }^{8}$ I en annan studie baserad på arbetsstatistik över löner för svenska verkstadsarbetare kring sekelskiftet 1900, visade Fay Lundh 
Nilsson att redan vid denna tid hade teknisk vidareutbildning en positiv inverkan på lönen. ${ }^{9}$

Jan Kuuse publicerade i sin avhandling 1970 korstabuleringar av ålder och arbetsinkomst under perioden 1925-1960 i fyra svenska städer (Stockholm, Göteborg, Malmö och Norrköping). ${ }^{10}$ Han jämförde män i tre yrken: murare, textilarbetare och folkskollärare. Murarna och textilarbetarna uppnådde sina maximala inkomster i 30-årsåldern, varefter de låg kvar på samma inkomstnivå till 6o-årsåldern, då inkomsterna föll kraftigt i samband med pensioneringen. ${ }^{11}$ Lärarna, som hade ett lönesystem med ålderstillägg, uppnådde sina maximala inkomster senare, i 50-årsåldern, och upplevde inte samma dramatiska inkomstsänkningar i 6o-årsåldern eftersom de omfattades av tjänstepensionsförmåner. ${ }^{12}$ Kuuse observerade också skillnader mellan de två arbetargrupperna: murarnas sysselsättning var mer präglad av konjunktur- och säsongsvariationer än textilarbetarnas, och den senare gruppen verkade i en mer "åldersvänlig arbetsmiljö" och hade en planare inkomstprofil än murarna. ${ }^{13}$

Utifrån tidigare forskning kan vi ana en skillnad i de typiska inkomstkarriärerna mellan det tidiga och det sena industrisamhället. I det tidiga industrisamhället, där få hade utbildning över grundskolenivå, var det arbetsplatsanknutna lärandet för de flesta koncentrerat till en kort period i unga år. Redan i början av 20-årsåldern var den genomsnittliga arbetaren fullärd. I det sena industrisamhället, där skolgången var längre, pågick också det arbetsplatsanknutna lärandet under en längre period och inkomstplatån inträdde betydligt senare. Förändringen kan ha berott dels på att yrken i allmänhet fick ett större inslag av lärande, dels på att själva yrkessammansättningen förändrades, det vill säga att andelen med relativt högkvalificerade jobb ökade.

Låt oss nu se hur sambandet mellan ålder och arbetsinkomster såg ut i den mogna industristaden Göteborg under perioden 1915-1943. Vi börjar med att betrakta denna period som en helhet. Vi slår alltså ihop observationer från alla panelår men räknar om inkomsterna till 1914 års prisnivå. ${ }^{14}$ Diagram 3.1a visar den genomsnittliga reala arbetsinkomsten i 1914 års prisnivå, för män och kvinnor, uppdelat 
Diagram 3.1. Genomsnittlig arbetsinkomst för män och kvinnor i olika åldrar, Göteborg 1915-1943 (kronor i 1914 års prisnivå). Källa: Totalpopulationen, GOPP.

a) Män och kvinnor 1915-1943

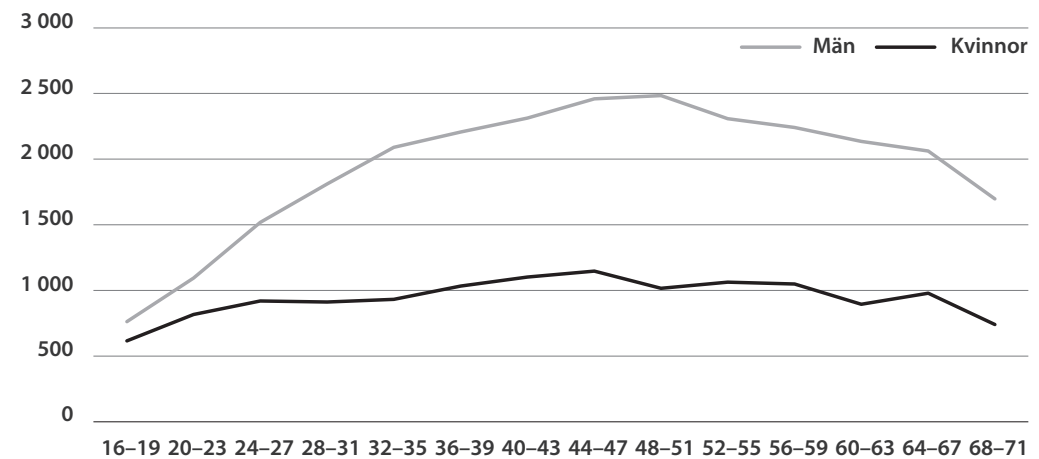

b) Män, uppdelat på perioder

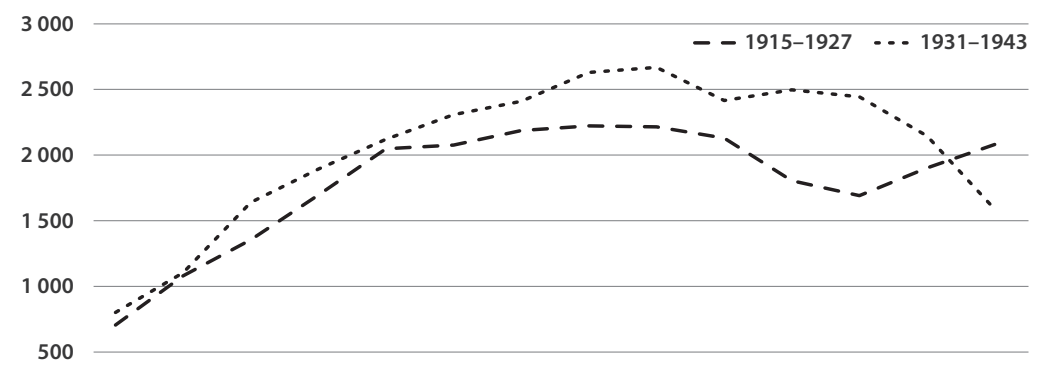

0

16-19 20-23 24-27 28-31 32-35 36-39 40-43 44-47 48-51 52-55 56-59 60-63 64-67 68-71

c) Kvinnor, uppdelat på perioder

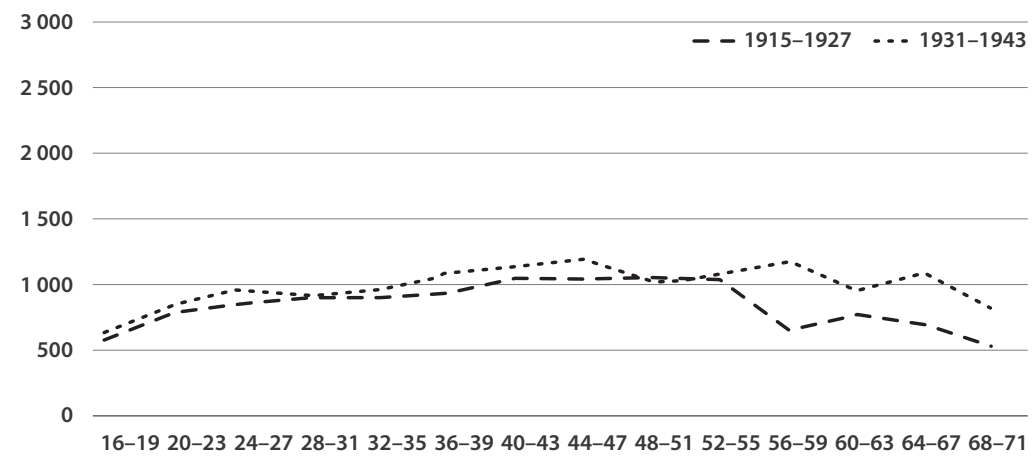


på åldersgrupper. ${ }^{15}$ Här ser man skillnaderna i inkomstnivå mellan män och kvinnor och förändringar över livscykeln. Inkomsterna är genomsnitt för respektive åldersgrupp för perioden som helhet. Eftersom Göteborgs befolkning växte har vi fler observationer i GOPP från de senare panelåren än för de tidigare.

I diagram 3.1b och c delar vi upp observationerna på panelåren före respektive efter 1931 för män och kvinnor för att fånga upp förändringar i undersökningspopulationens storlek och sammansättning samt den långsiktiga lönetrenden. I Diagram 3.1b ser vi att män tenderade att ha något högre genomsnittliga realinkomster från 1931 och framåt, särskilt efter 35 -årsåldern. ${ }^{16}$ Under den senare perioden var inkomsttillväxten mer utdragen över livscykeln. Det är fullt väntat i ljuset av tidigare historisk forskning om sambandet mellan ålder och inkomst. Inkomstprofilerna för männen i GOPP blir med tiden alltmer lika de profiler amerikanska forskare hittade på 1950-talet. Det kan delvis bero på ett ökat inslag av tjänstemän i befolkningen, men också på att kollektivavtalen, som fick högre täckningsgrad över tid, påverkade äldre mäns inkomster särskilt positivt. ${ }^{17}$

För kvinnor (diagram 3.1c) var sambandet mellan ålder och inkomst påfallande stabilt över tid. Den förändring som möjligen inträffar är att realinkomsterna för äldre kvinnor (över 55) var högre efter 1931.

De mönster vi har funnit ligger närmare en senindustriell inkomstprofil än en tidigindustriell. I Göteborg minskade arbetsinkomsterna dock mer markant i slutet av arbetslivet än vad forskarna i efterkrigstidens USA observerade.

När män och kvinnor jämförs i samma diagram, som i 3.1a, är nivåskillnaderna det mest slående. Män tjänade betydligt mer i alla åldersgrupper, möjligtvis med undantag för gruppen 16-19 år. I förhållande till mäns inkomster ser kvinnors inkomstprofil nästan helt platt ut. Så var det emellertid inte. Maria Stanfors och Joyce Burnette fann i sin studie av svenska tobaksarbetare i slutet av 180o-talet att inkomstprofilerna var påfallande lika för män och kvinnor ${ }^{18}$ och detsamma gäller i våra data från Göteborg under mellankrigstiden. 
Diagram 3.2. Genomsnittlig arbetsinkomst för män och kvinnor i olika åldrar, Göteborg 1915-1943 (index). Anm: Index 48-51 år = 100 för män, index 44-47 år $=100$ för kvinnor. Källa: Totalpopulationen, GOPP.

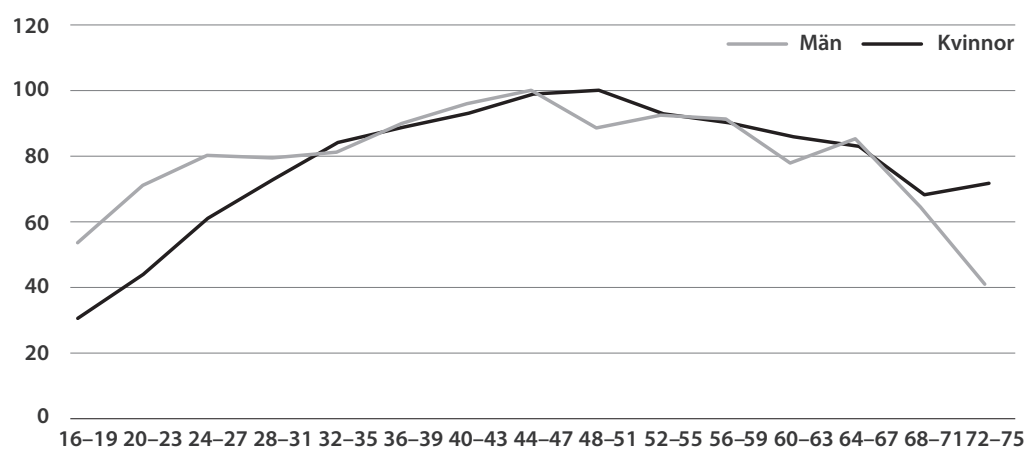

Diagram 3.2 visar arbetsinkomsten i relation till den högsta nivån under det typiska livsförloppet för män respektive kvinnor. Kvinnornas inkomstkurva under livsloppet hade ungefär samma form som männens, men nivån var lägre. Kvinnor nådde sin maximala inkomstnivå vid åldern 44-47 år och låg under större delen av sitt vuxna liv på en inkomstnivå som översteg 70 procent av den maximala inkomsten. Som pensionärer och unga vuxna hade de dock betydligt lägre arbetsinkomster än vad de maximalt tjänat. Män tjänade som mest i åldern 48-51 år. Jämfört med denna maximinivå var inkomsten i början av arbetslivet (16-23 år) betydligt lägre, 30-45 procent. Även efter pensioneringen var inkomsten betydligt lägre. Inkomstnivån för de mellanliggande åldersklasserna (24-39 och 56-67 år) var cirka 75-80 procent av maximum.

Inkomstskillnaderna mellan unga kvinnor och unga män i Göteborg var betydligt mindre än för högre åldersklasser. Ett sådant mönster har även iakttagits i andra studier. I London 1930 tjänade en 16årig kvinnlig textilarbetare över 90 procent av lönen för en jämnårig manlig arbetare; i 30-årsåldern var kvinnans lön endast 60 procent av mannens lön. ${ }^{19}$ Vad gäller ungdomslöner har ekonomisk-historikern Claudia Goldin utifrån en amerikansk horisont påmint om att många av de allra mest okvalificerade jobben, såsom springpojke och kontors- 
bud, var reserverade för unga män medan unga kvinnors ofta hade halvkvalificerade positioner som maskinskrivare eller stenograf. ${ }^{20}$

Även om mycket av forskningen om sambandet mellan ålder och inkomst har gällt män finns empiriska studier och teorier som inkluderar kvinnor, och som har jämfört könen. Sådan forskning utgår ofta från att kvinnor investerar mindre i lärande på arbetsplatsen, alternativt erbjuds färre möjligheter till sådant lärande, på grund av att de förväntas lämna yrkeslivet eller arbeta deltid i samband med familjebildning. ${ }^{21}$

En central fråga i forskningen om avkastningen på investeringar i humankapital har varit betydelsen av skolutbildning. I de mantalsoch inkomstlängder som bildar underlag till GOPP finns tyvärr ingen information om individers utbildning. Indirekt kan vi dock undersöka frågan genom att studera yrkesgrupper med olika krav på utbildning.

Det fanns relativt stora genomsnittliga inkomstskillnader mellan olika yrkesgrupper i Göteborg, och det fanns, som Kuuse visade i sin jämförelse av folkskollärare, murare och textilarbetare i fyra städer 1925-1960, även skillnader i hur inkomstnivån förändrades över livscykeln. För att få syn på skolutbildningens betydelse har vi undersökt arbetsinkomsten för personer som någon gång i vuxen ålder titulerades "verkstadsarbetare" respektive "ingenjör", med antagandet att ingenjörerna åtminstone hade examen från läroverk eller motsvarande. Vi följde personerna genom undersökningsperioden, även vid tidpunkter då de hade en annan yrkestitel, och registrerade deras arbetsinkomster i 1914 års prisnivå. Resultatet visas i diagram 3.3 och 3.4 .

Av diagram 3.3 framgår att ingenjörer hade betydligt högre arbetsinkomster än verkstadsarbetare. I de lägre åldersklasserna rörde det sig om upp till dubbelt så mycket och i åldersklasserna över 30 år om två till tre gånger så mycket. Denna högre inkomst kan ses som en utbildningspremie: genom att utbilda sig till ingenjörer i unga år fick dessa individer senare i livet en avkastning på investeringen i sitt humankapital i form av högre arbetsinkomst.

Diagram 3.4 visar den relativa inkomstutvecklingen över livscykeln för de båda yrkesgrupperna, med åldern 40-43 satt till 100. 
Diagram 3.3. Genomsnittlig arbetsinkomst för ingenjörer och verkstadsarbetare i olika åldrar, Göteborg 1915-1943 (kronor i 1914 års prisnivå). Källa: Totalpopulationen, GOPP.

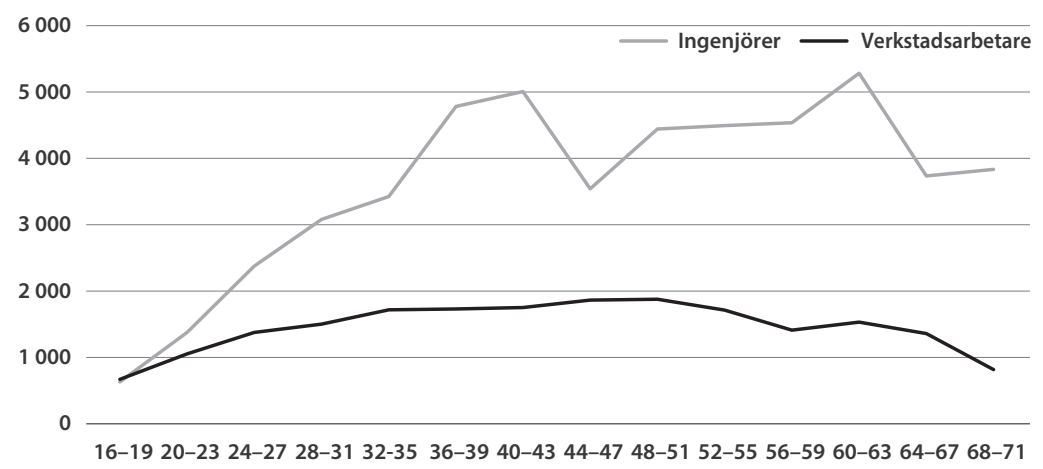

Diagram 3.4. Genomsnittlig arbetsinkomst för ingenjörer och verkstadsarbetare i olika åldrar, Göteborg 1915-1943 (index). Anm: Index 40-43 år = 100. Källa: Totalpopulationen, GOPP.

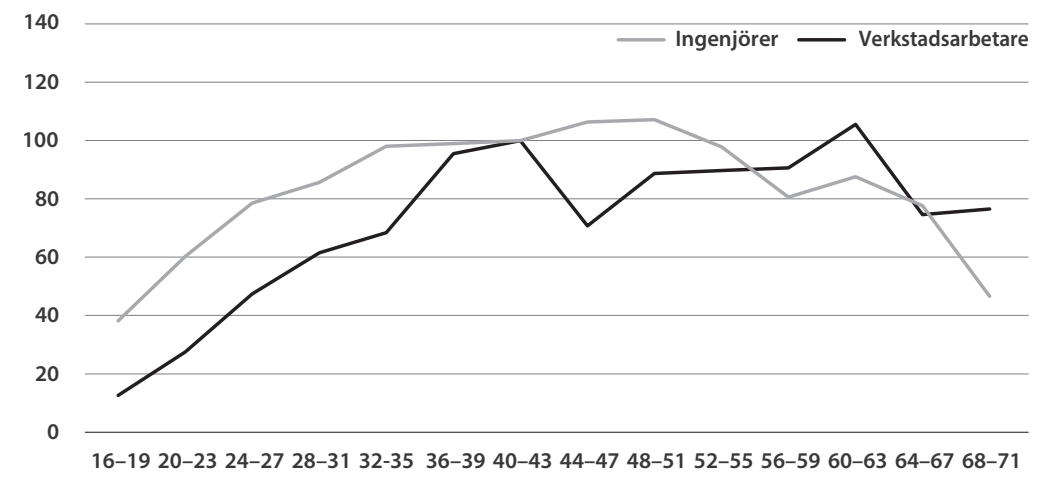

Vi ser att fram till 40-årsåldern tjänade verkstadsarbetare en större andel av sin maximiinkomst än ingenjörer: en verkstadsarbetare i åldern 24-27 år tjänade 80 procent av vad han skulle tjäna i åldern 40-43 år, en ingenjör bara knappt hälften. Å andra sidan höll sig en ingenjör som väl nått den maximala inkomstnivån kvar där betydligt längre än verkstadsarbetare, vars inkomst började minska från 50-årsåldern. Skillnaden mellan ingenjörers och verkstadsarbetares inkomstprofiler kan förklaras dels av att ingenjörer i ungdomen 


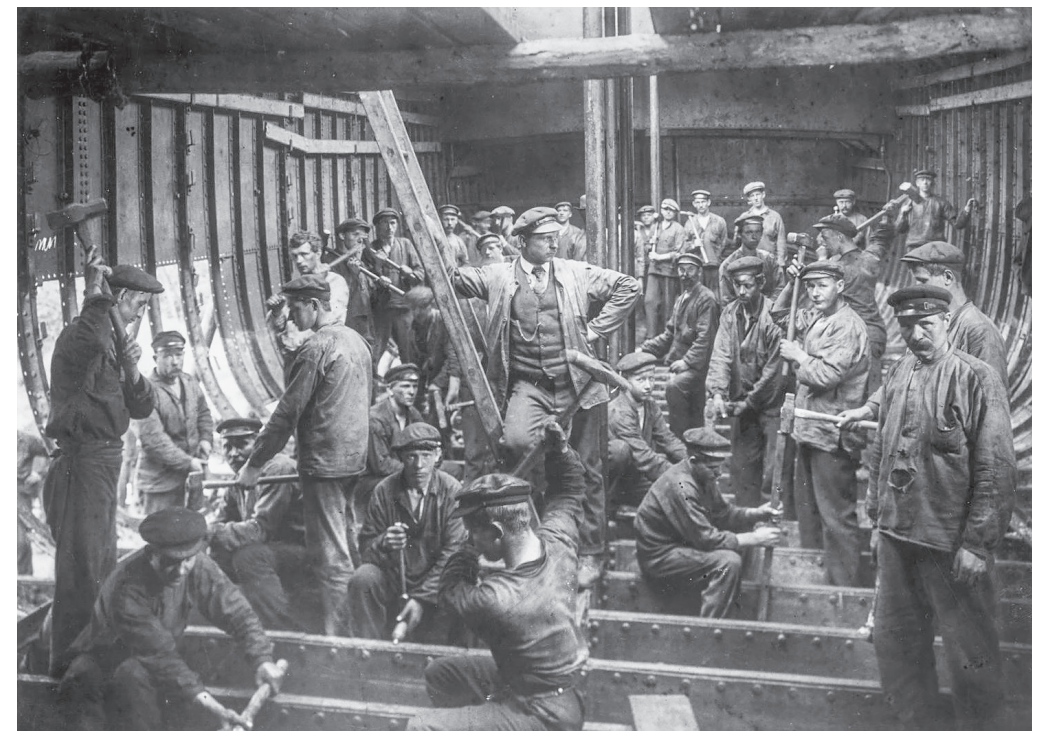

Bild 3.1. Ett arbetslag inne i ett fartygsskrov på Eriksbergs varv omkring 1910. Foto: okänd, Göteborgs stadsmuseum.

studerade och praktiserade för att öka värdet på sitt humankapital, vilket senare i livet gav avkastning i form av högre lön, dels av att ingenjörernas humankapital inte sjönk i värde med åldern lika snabbt som verkstadsarbetarnas, vilket hade större inslag av fysisk styrka och precision.

Om man jämför de personer som ingick i denna specialstudie, 34 ingenjörer och 136 verkstadsarbetare, är det uppenbart att de som blev ingenjörer studerade och praktiserade i yngre år, medan de som blev verkstadsarbetare började i liknande yrken eller helt okvalificerade yrken när de var unga.

\section{Giftermålet - olika spår för män och kvinnor}

Giftermålet var den viktigaste markören för övergången till vuxenlivet. Giftermålsåldern i vårt land var traditionellt hög, cirka 26 år för kvinnor och 28 för män. Så var det också i Göteborg. När man gifte sig förväntades man kunna bilda ett nytt, eget hushåll. 
Baserat på data från GOPP för hela perioden 1915-1943 har vi beräknat att gifta män i snitt tjänade 65 procent mer än ogifta män. Övertaget var mindre i unga år och som störst efter 40-årsdagen. Gapet mellan gifta och ogifta män vidgades fram till 1940-talet, varefter det minskade något. ${ }^{22}$ Inkomstskillnaderna berodde delvis på gruppernas ålders- och yrkessammansättning, men det fanns sannolikt också andra förklaringar.

Att gifta män tjänar mer än ogifta är ett av de mest robusta resultaten i såväl modern som historisk forskning om lönens bestämningsfaktorer. ${ }^{23}$ Fenomenet kallas i den teoretiska litteraturen marriage premium. ${ }^{24}$ Man kan tänka sig åtminstone tre slags förklaringar. För det första kan det röra sig om att äktenskapet gör män mer produktiva: i förhållande till sina ogifta bröder får de tillgång till bättre boende, kost och omvårdnad och kan därför prestera bättre. Denna förklaring bygger på att det är mannen som är familjeförsörjare och kvinnan som har huvudansvaret för hushållet. Så var det tveklöst i Göteborg under den period vi undersöker. ${ }^{25}$ För det andra kan giftermålet fungera som en selektering: de män som gifte sig var de som hade de egenskaper som krävs för familjebildning, till exempel förmågan att dra in arbetsinkomster till hushållet. För det tredje kan de gifta männens högre inkomster vara ett utslag av arbetsgivares favoritism: arbetsgivare kan exempelvis premiera gifta män för att begränsa personalomsättningen. Vi kan inom ramen för detta kapitel inte avgöra vilken av dessa förklaringar som är rimligast, troligen är alla relevanta.

Så långt om männen. För kvinnor fick giftermålet andra konsekvenser. De flesta kvinnor arbetade så länge de var ogifta, oavsett om de var kvar i föräldrahemmet, vilket de flesta var, eller bodde som inhyses eller i egen lägenhet. I samband med giftermålet, och framförallt i samband med det första barnets ankomst, slutade kvinnor att förvärvsarbeta utanför hemmet och stannade hemma med barnen så länge de var små. Senare kunde de återgå till förvärvsarbete om det behövdes, och bland dem som blev änkor var det vanligt att arbeta eller ta emot inneboende i hushållet. Mönstret motsvarade normerna i den så kallade enförsörjar- eller familjeförsörjarmodellen, med en arbetsdelning mellan makarna: mannen förvärvsarbetade utanför 
Diagram 3.5. Kvoten mellan arbetsinkomsten för män och kvinnor, uppdelat på gifta och ogifta i olika åldrar, Göteborg 1915-1943. Källa: Totalpopulationen, GOPP.

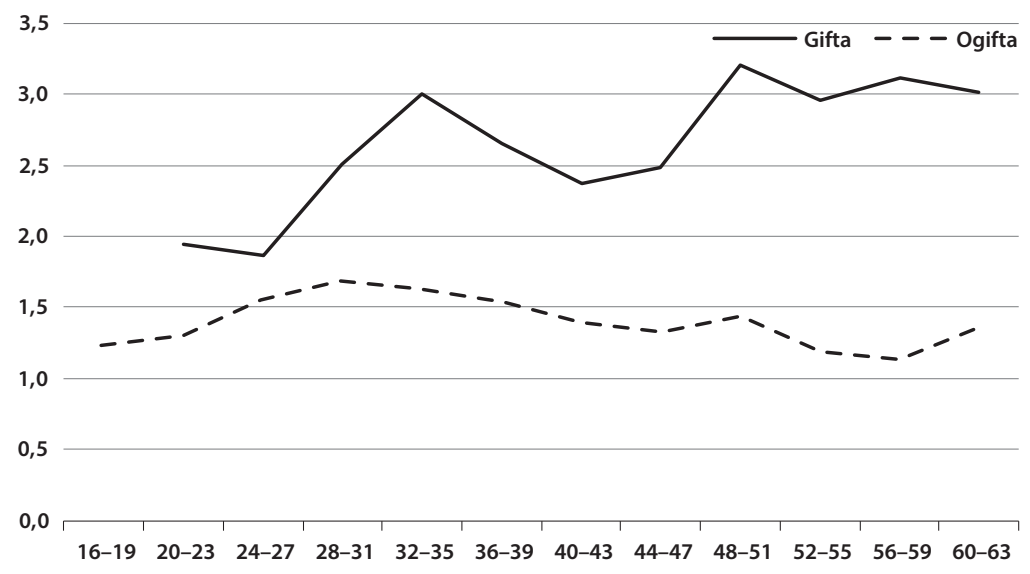

hemmet och stod för hushållets inkomster, kvinnan hade ansvar för barnen, kost och husrum. ${ }^{26}$ Denna könsarbetsdelning innebar att de flesta gifta kvinnor i Göteborg inte deklarerade några inkomster av tjänst alls men det fanns naturligtvis gifta kvinnor som avvek från normen.

I den moderna forskningen förväntas kvinnor som kombinerar familjeliv och förvärvsarbete ha lägre inkomster, inte minst till följd av att de ofta deltidsarbetar. En historisk studie baserad på den ovan nämnda undersökningen av tobaksarbetare i slutet av 1800-talet fann dock tecken på att arbetande mödrar kunde kompensera för kortare veckoarbetstid genom att arbeta intensivare. ${ }^{27}$

I allmänhet var det svårt för kvinnor att kombinera förvärvsarbete och ansvar för hemmets obetalda sysslor. I vårt material tjänade de gifta kvinnor som deklarerade inkomster av tjänst eller rörelse i genomsnitt 15 procent mindre än de ogifta. Att gifta män premierades inkomstmässigt medan gifta kvinnor straffades påverkar vår tolkning av inkomstgapet mellan män och kvinnor.

Män tjänade i genomsnitt mer än dubbelt så mycket som kvinnor (jämförelsen gäller personer med inkomster över noll kronor). Störst var skillnaden för gifta; i vissa åldersgrupper tjänade gifta män tre 


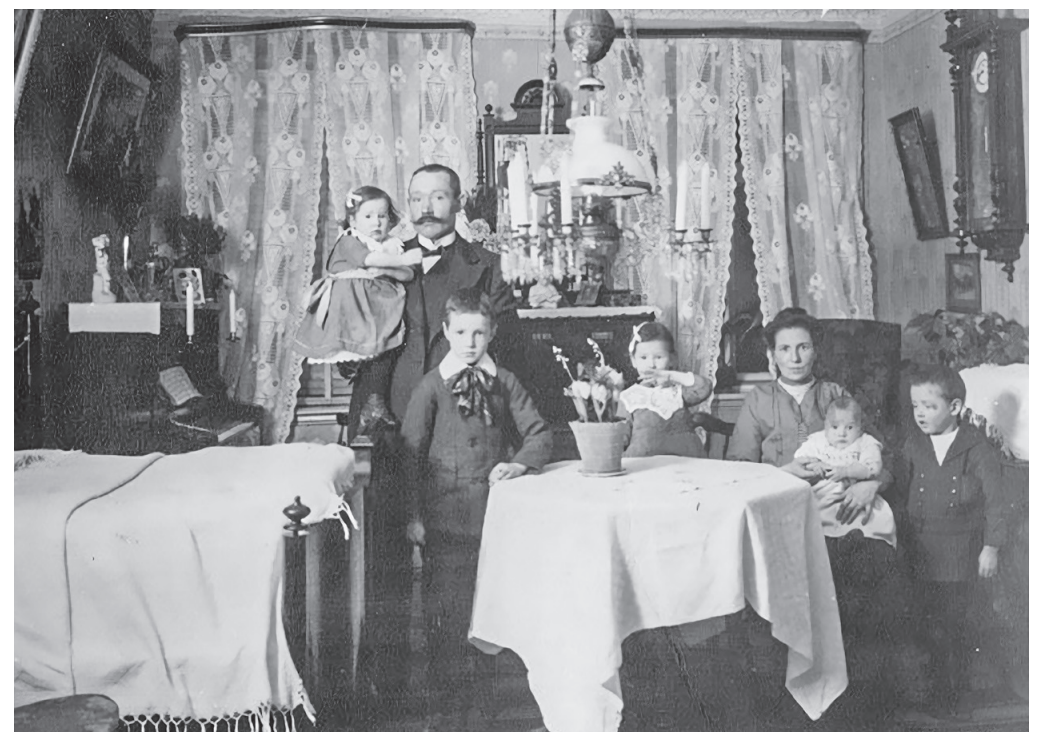

Bild 3.2. Interiör från den SJ-anställde banarbetaren Ahlströms hem, en lägenhet med ett rum och kök i Olskroken, omkring 1914. Foto: okänd, Göteborgs stadsmuseum.

gånger så mycket som gifta kvinnor. En viktig förklaring var sannolikt att gifta kvinnor ofta jobbade deltid. Inkomstgapet mellan ogifta män och kvinnor uppgick till 40 procent för perioden som helhet. Det överensstämmer med Sakari Heikkinens och Christer Lundhs studie baserad på den officiella lönestatistiken om inkomstgapet mellan manliga och kvinnliga arbetare i jordbruket under denna period (här var både män och kvinnor i allmänhet ogifta). ${ }^{28}$

Inkomstkurvan under livscykeln såg olika ut för män och kvinnor. Minst var inkomstskillnaden bland yngre: ogifta män i åldern 16-23 år tjänade 20-30 procent mer än jämnåriga ogifta kvinnor. Med åldern ökade inkomstskillnaden mellan män och kvinnor för att vara ganska stabil tills pensionen närmade sig.

Lönegap mellan män och kvinnor fanns också på yrkesnivå. De varierade med fördelningen mellan gifta och ogifta inom yrket, yrkesutövarnas ålder och befattningarnas arbetsinnehåll. Bland industriarbetare tjänade män 70-90 procent mer än kvinnor, bland folkskol- 
lärare 75 procent mer och bland banktjänstemän 60 procent mer. Det fanns yrkesgrupper där inkomstgapet var mindre, exempelvis tjänade manliga handels- och affärsbiträden bara 40 procent mer än kvinnliga.

\section{Faser i familjecykeln}

Familjens livscykel inleds med giftermålet och fortsätter tills familjen upplöses, exempelvis genom en av makarnas död. Hur faserna i familjens livscykel har sett ut med avseende på försörjningsmönster och familjemedlemmarnas roller har skiftat över tid. I det för- och tidigindustriella samhället förväntades alla bidra till försörjningen efter förmåga. I det mogna industrisamhället förväntades maken förvärvsarbeta och makan ta huvudansvaret för det obetalda reproduktiva arbetet i hemmet. Även barnens roll i familjen förändrades. Det barnarbete som vi förknippar med för- och tidigindustriella samhällen minskade till följd av regleringar, teknisk utveckling och skolreformer. ${ }^{29}$ Istället för att barnen skulle bidra till familjens försörjning lade föräldrarna mer resurser på barnen, exempelvis genom att låta dem gå i skolan. ${ }^{30}$ Det dröjde dock länge innan skolgången omfattade hela tonårs- och ungdomstiden fram till myndighetsåldern för bredare grupper. I det mogna industrisamhället fanns särskilda ungdomsjobb, exempelvis som springpojke och kontorsbud - jobb som var lågt avlönade konjunkturkänsliga. ${ }^{31}$

När det gäller familjens inkomster kan vi tänka oss att under fasen när barnen är små är inkomsterna och konsumtionsutrymmet begränsade. I en senare fas kan äldre barn bidra med arbetsinkomster, vilket kan underlätta försörjningen av de yngre barnen. Senare, när alla barnen är stora nog att förvärvsarbeta men fortfarande bor kvar i föräldrahemmet, bidrar de starkt till ett ökat välstånd för familjen. Högre giftermålsålder och hushåll med många vuxna ogifta barn (se kapitel 6) indikerar att detta var en strategi som familjer använde under mellankrigstiden för att underlätta föräldrarnas pensionering.

Inkomstskillnader mellan olika hushållstyper i svenska städer under 1900-talets första halva har undersökts tidigare, men sällan 
med syftet att belysa inkomstskillnader över familjecykeln. ${ }^{32}$ Det finns emellertid ett par studier som vi vill nämna.

Ekonomisk-historikern Martin Järnek har undersökt hur hushållens inkomstutveckling varierat med hushållsföreståndarnas ålder för

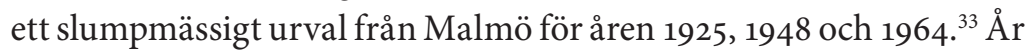
1925 uppnådde det typiska Malmöhushållet sin högsta sammanlagda disponibla inkomst när hushållsföreståndaren var i 50-årsåldern. År 1948 var hushållsföreståndaren något yngre, 45-50 år, när den maximala inkomsten uppnåddes. Intressant att notera är att hushållsföreståndarens individuella inkomsttopp bägge åren inträffade ungefär fem år före hushållets inkomsttopp. Från det att hushållsföreståndaren passerat 50 började alltså andra familjemedlemmars inkomster utgöra en allt större andel av hushållets samlade kassa. ${ }^{34}$

Järnek bryter inte ned sina resultat på yrken. Skillnader mellan hushåll som företräds av innehavare av olika yrken är däremot centrala i Kent Olssons undersökning av mantals- och inkomstlängder i Göteborg åren 1919, 1925, 1929, 1938 och 1960. ${ }^{35}$ Hans undersökning omfattar delvis samma geografiska område och period som GOPP men skiljer sig i fråga om urvalsprinciper. Istället för ett slumpmässigt urval studerar Olsson nio yrkesgrupper som representerar olika inkomstskikt: civilingenjörer, läroverksadjunkter, läroverksingenjörer, kontorister, brevbärare, svarvare, byggnadssnickare, byggnadsarbetare och textilarbetare. ${ }^{36}$ Vidare urskiljer Olsson fem hushållstyper: ensamstående, gifta utan barn, gifta med barn under 16 år, gifta med minst ett barn som fyllt 16 år samt ofullständiga hushåll. ${ }^{37} \mathrm{Ur}$ ett livscykelperspektiv är denna indelning av hushållen inte optimal. De ensamstående kan exempelvis inkludera såväl personer som ännu inte bildat familj som personer vars make/maka avlidit och vars barn flyttat ut. Två av hushållstyperna - hushåll med barn under respektive över 16 år - kan emellertid belysa inkomstutvecklingen över en del av familjens livscykel.

Hushåll med barn under 16 år hade i Olssons undersökning betydligt lägre inkomster än hushåll där minst ett av barnen hade fyllt 16. För familjer företrädda av manliga svarvare kunde detta inkomstgap uppgå till 35-40 procent under 1920 - och 1930 -talen. ${ }^{38}$ Skillnader i samma 
Tabell 3.1. Medianinkomster samt makans och barnens andel av de totala inkomsterna för olika hushållstyper och åldersgrupper, Göteborg 1915-1943 (kronor; procent). Anm: Endast hushåll där urvalspersonen är gift. Med ålder avses urvalspersonens ålder. Medianinkomsterna har deflaterats med KPI för 1914. Källa: GOPP, Totalpopulationen.

\begin{tabular}{|c|c|c|c|c|c|c|}
\hline \multirow[t]{2}{*}{ Typ nr } & \multirow[t]{2}{*}{ Beskrivning } & \multirow[t]{2}{*}{ Ålder } & \multirow[t]{2}{*}{$\mathrm{N}$} & \multicolumn{3}{|c|}{ Hushållets inkomster } \\
\hline & & & & Median (kr) & Maka (\%) & Barn (\%) \\
\hline 1 & Utan barn & $20-29$ & 394 & 2206 & 20 & - \\
\hline 2 & Med barn under 16 & $20-29$ & 689 & 1796 & 5 & - \\
\hline 3 & Med barn över 16 & $20-29$ & 2 & - & - & - \\
\hline 4 & Med barn under och över 16 & $20-29$ & 1 & - & - & - \\
\hline 5 & Utan barn & $30-39$ & 511 & 2283 & 17 & \\
\hline 6 & Med barn under 16 & $30-39$ & 1580 & 2079 & 4 & 0 \\
\hline 7 & Med barn över 16 & $30-39$ & 16 & 2480 & 1 & 16 \\
\hline 8 & Med barn under och över 16 & $30-39$ & 87 & 2383 & 2 & 16 \\
\hline 9 & Utan barn & $40-49$ & 330 & 2277 & 12 & - \\
\hline 10 & Med barn under 16 & $40-49$ & 717 & 2171 & 4 & 0,3 \\
\hline 11 & Med barn över 16 & $40-49$ & 263 & 3174 & 7 & 23 \\
\hline 12 & Med barn under och över 16 & $40-49$ & 568 & 3007 & 4 & 23 \\
\hline 13 & Utan barn & $50-59$ & 252 & 1848 & 9 & - \\
\hline 14 & Med barn under 16 & $50-59$ & 113 & 2215 & 4 & - \\
\hline 15 & Med barn över 16 & $50-59$ & 546 & 3632 & 4 & 36 \\
\hline 16 & Med barn under och över 16 & $50-59$ & 345 & 3345 & 2 & 38 \\
\hline
\end{tabular}

storleksordning fanns mellan hushåll med underåriga och äldre barn bland andra arbetargrupper. Hur inkomsterna förändrades mellan familjecykelns övriga faser är svårare att få en bild av utifrån Olssons undersökning. I GOPP finns emellertid information inte bara om enskilda individer utan också om deras hushåll.

De gifta individer som ingår i undersökningen levde i hushåll som i genomsnitt omfattade 3,5 personer. ${ }^{39} \mathrm{Om}$ vi begränsar oss till de 5000 observationer som gällde gifta personer med barn i hushållet, minderåriga och vuxna, är hushållsstorleken naturligtvis större, i genomsnitt 4,2 personer.

För att få en uppfattning om hur de sammantagna inkomsterna varierade över familjecykeln har vi delat in de gifta urvalspersonernas hushåll i om det fanns barn under respektive över 16 år i hushållet 
samt i fyra åldersgrupper utifrån urvalspersonens ålder (20-29, 30-39, 40-49, 50-59). Vi får då 16 hushållstyper, varav vi har beräknat reala medianinkomster för 14; typ nr 3 och 4 i tabell 3.1 representerat med endast några få observationer har uteslutits.

Trots att tabell 3.1 beskriver hushållen efter mycket enkla kriterier ger den en uppfattning om den rika variation av hushållstyper som fanns i mellankrigstidens Göteborg. Bland hushåll i 20-årsåldern tjänade de som inte hade barn klart mer än de som hade barn, vilket är rimligt med tanke på att kvinnor utan barn oftare förvärvsarbetade. De hushåll i 30-årsåldern som fortfarande inte hade barn hade något högre inkomster än de talrika hushåll som hade minst ett underårigt barn, men skillnaden var inte så stor som i 20-årsåldern. I 30-årsåldern hade mannen i typfallet skaffat sig en bättre position på arbetsmarknaden och tjänade mer än i 20-årsåldern.

Även bland hushåll i 40-årsåldern var hushåll med barn under 16 år talrikast. I denna hushållstyp stod makan för ungefär 4 procent av inkomsterna, att jämföra med 7 procent i de hushåll där det fanns minst ett barn över 16. Denna hushållstyp hade också de högsta medianinkomsterna, vilket barnens förvärvsarbete bidrog till i hög grad (23 procent av inkomsterna).

Bland urvalspersonerna i 50-årsåldern var hushållstypen med barn över 16 den mest frekventa och likaså den med de högsta medianinkomsterna. Barnen stod för över en tredjedel av inkomsterna (36 procent).

Sammanfattningsvis kan sägas att hushållets maximala medianinkomster uppnåddes i 50-årsåldern i de fall då det fanns hemmavarande barn över 16 år. Kvinnornas bidrag till hushållets inkomster minskade vanligtvis med åldern och i och med att barn tillkom och blev äldre. När data tabuleras såsom i tabell 3.1 finns inget som tyder på att de gifta kvinnornas andel av hushållets inkomster ökade med stigande ålder. Det kunde säkert hända att makor i denna fas ökade sitt arbetskraftsutbud för att i någon mån kompensera för makens sjunkande inkomst, särskilt om denne drabbades av arbetslöshet eller sjukdom, men i typfallet deklarerade inte kvinnor i detta skede av familjecykeln några inkomster. Sannolikt yttrade sig ett ökat arbets- 
kraftsutbud bland kvinnor i denna ålder främst i deltidsarbete eller informellt arbete av det slag som historikern Ann-Kristin Högman visat i en studie av äldre ogifta kvinnor i Göteborg på 1920-talet. ${ }^{40}$ Detsamma gäller sannolikt barns förvärvsarbete före 16 års ålder. ${ }^{41} \mathrm{I}$ GOPP finns endast enstaka exempel på att barn deklarerade inkomster. Från och med 16 års ålder var det däremot vanligt att hemmavarande barn bidrog till hushållets försörjning. Även om det, särskilt när det gäller pojkar, inte var reguljära anställningar av det slag som vuxna hade (se kapitel 6) gjorde de hemmavarande barnens arbete väsentlig skillnad för hushållets ekonomi.

Barnens fortsatta betydelse för familjens försörjning tycks vara ett kännetecken för det mogna industrisamhällets familjecykel, såsom den framträder i Göteborg. Det var dock inte frågan om barnarbete i fabriker utan snarare om ungdomar som bodde kvar i hemmet. Hemmavarande barn bidrog till 17 procent av alla de hushållsinkomster som vi kan observera i GOPP. Barnens bidrag varierade från att vara litet till att utgöra hushållets totala inkomst.

Hushållet var en institution som överförde resurser från föräldrarna till barnen, i form av mat och logi när de bodde i föräldrahemmet och långsiktigt genom gåvor och arv. Men det fanns också en överföring från barn till föräldrar när barnen blivit vuxna, särskilt om de bodde med föräldrarna. Det finns i GOPP flera exempel på att vuxna barn flyttade tillbaka till föräldrahemmet när den ena föräldern dött eller båda var gamla och skröpliga.

Genom att man delade på kostnaderna för boende och mat kunde familjens resurser växa. Hur överskottet fördelades inom familjen kan vi inte veta; förmodligen kunde både barn och föräldrar tjäna på affären. I etnologisk forskning finns exempel på att hemmavarande barn behöll en större andel av sina inkomster med stigande ålder: föräldrarna tog hand om 12-åringens intjänade slantar, men den hemmaboende 17-åringen fick behålla en större andel av sin lön.

Mantals- och inkomstlängder ger inga direkta uppgifter om hushålls levnadsstandard och kapacitet att spara (se textrutan på sida 91), men vi kan diskutera levnadsstandard utifrån antaganden om familjemedlemmarnas konsumtionsbehov vid olika åldrar. Genom 


\section{Snörmakare minns hur han sparade ihop till sin första bostad}

Möjligheterna att spara skiftade över livs- och familjecykeln, vilket framgår av berättelsen av en gift man i Olivedal.

Jag har nämnt om att pappa bodde i köket i vår lägenhet på Vegagatan. Jag gjorde emellertid fram till 1926-1927 en, enligt min mening, verklig prestation. Jag sparade ihop $1250 \mathrm{kr}$ till en insats i HSB. Under den tiden fick vi försaka allt annat. Resultatet blev att vi fick en HSB-lägenhet på 2 rum och kök. Pappa fick då det ena rummet. Han bodde kvar tills han 1930 kom in på Vasa sjukhus. (Nilsson 1979, 5 50)

Mannen i ovanstående vittnesmål var född 1891 och var enligt egen utsago "den sista snörmakaregesällen som utbildades i stan" (Nilsson 1979, s 46). Han var i 35-årsåldern när han lyckades spara ihop till en insatslägenhet, något som sannolikt underlättades av att han under denna period befordrades till verkmästare. Sparbeloppet motsvarade drygt hälften av en normal årslön för en yrkesarbetare. Det framgår inte av berättelsen huruvida pappan bidrog med inkomster till hushållets ekonomi.

att utifrån hushålls storlek och sammansättning beräkna så kallade konsumtionsenheter visade Olsson att det i allmänhet fanns ett negativt samband mellan hushållstorlek och levnadsstandard i Göteborg under hans undersökningsperiod, 1919-1960. ${ }^{42}$ Men som historikern Johannes Daun har framhållit får vi inte glömma att hushåll har en förmåga att anpassa sig efter rådande ekonomiska omständigheter. ${ }^{43}$ Den stora barnfamiljen kunde anpassa sin konsumtion för att få hushållskassan att räcka till, exempelvis genom att minska inslaget av kött och mejeriprodukter i kosten. ${ }^{44}$ Att ta in inneboende när barnen flyttade hemifrån kunde vara ett sätt för äldre par eller ensamstående kvinnor att få in extrainkomster. ${ }^{45}$

\section{Slutsatser}

I detta kapitel har vi undersökt inkomstskillnader på individ- och hushållsnivå över livscykeln. Kapitlets huvudsakliga bidrag består i att urskilja mönster i sambanden mellan ålder och inkomst, uppdelat 
på kön, yrke, civilstatus samt familjesituation, och sätta dessa mönster i relation till tidigare forskning.

På individnivån fann vi mönster som påminner mer om de inkomstprofiler över livet som rådde under efterkrigstiden, med en relativt utdragen period av inkomsttillväxt, än om 180o-talets inkomstprofiler, med en kortare period av tillväxt i början av 20-årsåldern. Män och kvinnor hade liknande inkomstprofiler, men kvinnors inkomster låg på en lägre nivå och varierade mindre under livscykeln, något som sannolikt hängde samman med att kvinnors arbeten inte medgav lika stora möjligheter till arbetsplatsanknutet lärande.

Äktenskapet påverkade mäns och kvinnors inkomster på olika sätt. Gifta män hade högre inkomster än ogifta, och gifta kvinnor hade mindre tid till förvärvsarbete och lägre inkomster. Familjens inkomster under olika faser påverkades mycket av mannens inkomster, men i förekommande fall också av hemmavarande barn. Det senare förtjänar att betonas. Även om det rena barnarbetet i Göteborgs fabriker hade upphört under vår undersökningsperiod var ungdomars förvärvsarbete fortsatt betydelsefullt också i det mogna industrisamhället.

De mönster som vi presenterat i detta kapitel ska ses som ett avstamp för vidare forskning. När det gäller individers inkomstutveckling är en viktig fråga huruvida den påverkades positivt eller negativt av rörlighet på arbetsmarknaden. När det gäller hushållens inkomster över familjecykeln går det att vidareutveckla de grundläggande samband som vi dokumenterat i detta kapitel, exempelvis genom att studera i vilken mån mönstren rubbades i samband med ekonomiska kriser i samhället eller dödsfall i hushållet, samt att gå vidare med analyser av hushållens levnadsstandard och sparande. Verkligheten rymmer betydande variationer när det gäller hushållstyper och inkomstförhållanden som väntar på att utforskas.

\section{Noter}

1 För aktuell forskning om sparande över livscykeln på data som helt eller delvis omfattar den tidsperiod som behandlas i denna bok, se Andersson, Eriksson \& 
Lindmark 2010, Bäcklund \& Lilja 2014; Bäcklund \& Lilja 2019, Lilja \& Bäcklund 2013a,b samt Kenttä 2020.

2 För närmare presentation av GOPP, se kapitel 1 och appendix.

3 Becker 1964 .

4 Mincer 1974, s 66.

5 Mincer 1974.

6 Psacharopoulos \& Patrinos 2018. För en kritisk diskussion om detta antagande, se Murphy \& Welsch 1990.

7 Hatton 1997.

8 Stanfors \& Burnette 2015.

9 Lundh Nilsson 2007.

10 Kuuse 1970.

11 Hatton 1997 och Stanfors \& Burnette 2015 fann att arbetare nådde sin maximala inkomst när de var något yngre än vad Kuuse föreslog.

12 Den folkpension som arbetarna hade att försörja sig på var så låg att den fram till 1946 inte ens behövde deklareras.

13 Kuuse 1970, s 67.

14 Se även kapitel 9, diagram 9.3, där inkomstutvecklingen för en kohort män studeras över tid.

15 Observera att underlaget för beräkningar av inkomster i detta kapitel enbart inkluderar personer med en inkomst över noll.

16 Undantaget är bland de allra äldsta (68-71 år). Denna skillnad kan dock vara utslag av en rent slumpmässig variation, det rör sig om ett litet antal observationer för bägge delperioderna.

17 Ulf Olsson (1970, s 90) har i en studie av verkstadsindustrin visat att lönerna för arbetare över 60 i förhållande till lönerna för gruppen 21-59 år ökade markant under 1920- och 1930-talen. Från att ha varit ungefär 80 procent 1920 uppgick de till drygt 95 procent i början av 1940-talet. Olssons resultat tyder på att inkomstprofilerna över tid närmade sig den senindustriella typen och att det inte enbart berodde på att tjänstemännen blev fler. Se även Johnson (2003, s 241), som funnit en liknande utveckling bland manliga arbetare i England under perioden 1833 till 1930, dock för det mer begränsade åldersspannet 10-50 år. År 1833 tjänade en 50-årig manlig arbetare i genomsnitt 80 procent av vad hans kollegor i åldern 30-34 år gjorde; 1930 tjänade 50-åringen lika mycket som de.

18 Stanfors \& Burnette 2015.

19 Johnson 2003, s 243.

20 Goldin 2006.

21 Ibland föreslås det motsatta orsakssambandet: att kvinnors yrkesliv är kortare på grund av att de inte får några chanser att vidareutbilda sig och göra karriär (Owen 2001).

22 Totalpopulationen, GOPP.

23 För exempel på historisk forskning som visat att gifta män har högre inkomster än ogifta, även efter kontroll för andra karaktäristika, se Lundh Nilsson 2007 samt Stanfors et al 2014, som bygger på svenska arbetsstatistiska undersökningar från sekelskiftet 1900. Samma mönster uppträder i flera av de yrkesgrupper i Chicago 1960 som undersökts av Rees \& Shultz (1970, s 168-169).

24 Korenman \& Neumark 1991. 
25 Lane 2004.

26 Janssens 1997; van Poppel et al 2009.

27 Burnette \& Stanfors 2012.

28 Heikkinen \& Lundh 2021.

29 Olsson 1980; de Coninck-Smith 1997.

30 Alter 1988; Daun 2016.

31 Håkansson \& Karlsson 2018.

32 Skiftande metodik gör det även svårt att jämföra studier av hushållens inkomster med varandra (Gaunitz 1973).

33 Järnek 1971.

34 Järnek 1971.

35 Olsson 1972.

36 För tre av yrkesgrupperna (läroverksadjunkter, kontorister och textilarbetare) skiljer han dessutom mellan hushåll företrädda av män respektive kvinnor.

37 De ofullständiga hushållen saknar en av makarna men har flera familjemedlemmar. De utgör alltså en restpost. Här kan vi såväl finna hushåll där hushållsbildarna separerat eller där en av hushållsbildarna avlidit.

38 Olsson 1972, s 179.

3970 procent ingick i hushåll med 2-4 medlemmar. Mindre än 1 procent av observationerna refererade till hushåll med över 8 medlemmar. Cirka 8 procent av observationerna avsåg ensamhushåll, huvudsakligen änkefolk, frånskilda och gifta som inte bodde ihop med maken.

40 Högman 2004.

41 Etnologen Gösta Arvastson skriver (1987, s 70): "Tillfälliga behov av pengar gjorde att även småpojkar sökte sig till arbetsplatserna." Arvastson har hittat exempel på att pojkar i åttaårsåldern arbetade med tidningsutbärning i Göteborg.

42 Olsson 1972, s 214.

43 Daun 2016, s 186-198.

44 I en aktuell studie baserad på levnadskostnadsundersökningarna från 1913-1914, där ett antal hushåll från Göteborg ingår, ger ekonomisk-historikern Tony Kenttä (2020) en mer pessimistisk bild av hushållens möjligheter att anpassa sin konsumtion. Vissa av hushållen tvingades skuldsätta sig eller uppsöka en pantbank för att hantera tillfälliga inkomstminskningar.

45 Högman 2004. 